\title{
CORROSION TESTING IN SIMULATED TANK SOLUTIONS
}

\author{
Elizabeth N. Hoffman
}

SEPTEMBER 2010

Savannah River National Laboratory

Savannah River Nuclear Solutions

Aiken, SC 29808 


\section{DISCLAIMER}

This work was prepared under an agreement with and funded by the U.S. Government. Neither the U. S. Government or its employees, nor any of its contractors, subcontractors or their employees, makes any express or implied:

1. warranty or assumes any legal liability for the accuracy, completeness, or for the use or results of such use of any information, product, or process disclosed; or

2. representation that such use or results of such use would not infringe privately owned rights; or

3. endorsement or recommendation of any specifically identified commercial product, process, or service.

Any views and opinions of authors expressed in this work do not necessarily state or reflect those of the United States Government, or its contractors, or subcontractors.

Printed in the United States of America

Prepared for

U.S. Department of Energy 
Key Words:

Corrosion

Pitting

Retention:

Permanent

\title{
CORROSION TESTING IN SIMULATED TANK SOLUTIONS
}

\author{
Elizabeth N. Hoffman
}

SEPTEMBER 2010

Savannah River National Laboratory

Savannah River Nuclear Solutions

Savannah River Site

Aiken, SC 29808

Prepared for the U.S. Department of Energy Under

Contract Number DE-AC09-08SR22470 


\section{REVIEWS AND APPROVALS}

E.N. Hoffman, Co-author, Materials Performance \& Corrosion Technology, SRNL Date

B.J. Wiersma, Technical Reviewer, Material Performance \& Corrosion Technology, SRNL

Date

K.E. Zeigler, Manager, Material Performance \& Corrosion Technology, SRNL Date

K.D. Boomer, Program Manager, Washington River Protection Solutions

Date

J.L. Castleberry, Project Manager for Double Shell Tank Integrity Project and Single Shell Tank Integrity Project, Washington River Protection Solutions

Date 


\title{
LIST OF ACRONYMS
}

\author{
CPP Cyclic Potentiodynamic Polarization \\ PNNL Pacific Northwest National Laboratory \\ RDE Rotating Disc Electrode \\ SEM Scanning Electron Microscope \\ SRNL Savannah River National Laboratory
}




\subsection{EXECUTIVE SUMMARY}

Three simulated waste solutions representing wastes from tanks SY-102 (high nitrate, modified to exceed guidance limits), AN-107, and AY-102 were supplied by PNNL. Out of the three solutions tested, both optical and electrochemical results show that carbon steel samples corroded much faster in SY-102 (high nitrate) than in the other two solutions with lower ratios of nitrate to nitrite. The effect of the surface preparation was not as strong as the effect of solution chemistry. In areas with pristine mill-scale surface, no corrosion occurred even in the SY-102 (high nitrate) solution, however, corrosion occurred in the areas where the mill-scale was damaged or flaked off due to machining.

\subsection{INTRODUCTION}

Localized corrosion in the form of pitting in the vapor space of tank walls is an ongoing challenge to overcome in maintaining the structural integrity of the liquid waste tanks at the Savannah River and Hanford Sites. It has been shown that the liquid waste condensate chemistry influences the amount of corrosion that occurs along the walls of the storage tanks. To minimize pitting corrosion, an effort is underway to gain an understanding of the pitting response in various simulated waste solutions. Electrochemical testing has been used as an accelerated tool in the investigation of pitting corrosion. [1]

While significant effort has been undertaken to evaluate the pitting susceptibility of carbon steel in various simulated waste solutions, additional effort is needed to evaluate the effect of liquid waste supernates from six Hanford Site tanks (AY-101, AY-102, AN-102, AN-107, SY-102 (high $\mathrm{Cl}^{-}$), and SY-102 (high nitrate)) on carbon steel. Solutions were formulated at PNNL to replicate tank conditions, and in the case of SY-102, exceed $\mathrm{Cl}^{-}$and $\mathrm{NO}_{3}{ }^{-}$ conditions, respectively, to provide a contrast between in and out of specification limits.

The majority of previous testing has been performed on pristine polished samples. To evaluate the actual tank carbon steel surface, efforts are needed to compare the polished surfaces to corroded and mill-scale surfaces, which are more likely to occur in application. Additionally, due to the change in liquid waste levels within the tanks, salt deposits are highly likely to be present along the tank wall. When the level of the tank decreases, a salt deposit will form as the solution evaporates. The effects of this pre-existing salt, or supernate deposit, are unknown at this time on the corrosion effect and thus require investigation.

Additionally, in the presence of radiation, moist air undergoes radiolysis [2, 3], forming a corrosive nitric acid condensate. This condensate could accelerate the corrosion process in the vapor space. To investigate this process, an experimental apparatus simulating the effects of radiation was designed and constructed to provide gamma irradiation while coupons are exposed to a simulate tank solution. Additionally, ammonia vapors will also be introduced to further represent the tank environment. 


\subsection{EXPERIMENTAL}

\subsection{EFFORT 1: ELECTROCHEMICAL TESTING USING SIMULATED TANK SOLUTIONS}

Prior to electrochemical testing, samples were characterized using X-ray diffraction and SEM/EDS with particular focus on the corrosion-scale and mill-scale.

To minimize simulant usage, a BASi RDE-2 (rotating disc electrode) instrument was used for electrochemical testing with the sample rotation capabilities disabled. The RDE-2 setup requires $\sim 20 \mathrm{ml}$ of solution per run. Due to the small amount of solution required, the sample and electrodes are also miniaturized. Electrochemical cyclic potentiodynamic polarization testing was performed on $3.00 \mathrm{~mm}$ diameter ASTM A537 carbon steel tapped into mounting blanks. All testing was performed at $40{ }^{\circ} \mathrm{C}$ in solution with air in the vapor space above the solution. A platinum mesh counter electrode and an $\mathrm{Ag} / \mathrm{AgCl}$ reference electrode connected to a Luggin bridge were used in the cyclic potentiodynamic polarization testing. The potential was increased at $0.5 \mathrm{mV} / \mathrm{sec}$ up to a current density of $1.0 \times 10^{-4}$ Amps $/ \mathrm{cm}^{2}$. Runs were terminated when the reverse potential equaled the original open circuit potential.

Cyclic potentiodyanmic polarization testing was performed on A537 carbon steel in bulk solutions simulating vapor space supernates supplied by EMSL (A. Felmy). In particular, the testing focused on:

1) The effect of the pre-existing surface layer (corroded, mill-scale, or polished) on pitting susceptibly in A537 carbon steel.

2) The effect of supernate deposits susceptibility in A537 carbon steel.

Coupons of A537 carbon steel were used with surfaces of:

1) Mill-scale (actual mill-scale direct from manufacturer's processing)

2) Corroded (corroded during storage via exposure to laboratory atmosphere)

3) Polished, $800 \mathrm{SiC}$ grit

4) Pre-salt on Polished, $800 \mathrm{SiC}$ grit

The compositions of the supplied simulants are listed in Tables 1-3.

Table 1 SY 102 data from 2/4/2004 (high NO3), pH=9.90

\begin{tabular}{|c|c|c|c|c|c|}
\hline & Molarity & Salt compound & Molarity & MW (g) & $\begin{array}{c}\text { Mass (g) for } \\
\mathbf{1 L}\end{array}$ \\
\hline $\mathrm{Na}^{+1}$ & 4.641 & & 4.641 & & \\
\hline $\mathrm{Al}^{+3}$ & 0.069 & $\mathrm{NaAlO}_{2}$ & 0.069 & 81.97 & 5.659 \\
\hline $\mathrm{K}^{+1}$ & 0.001 & $\mathrm{KHCO}_{3}$ & 0.001 & 100.114 & 0.056 \\
\hline $\mathrm{Br}^{-1}$ & 0.074 & $\mathrm{NaBr}$ & 0.074 & 102.89 & 7.581 \\
\hline $\mathrm{Cl}^{-1}$ & 0.013 & $\mathrm{NaCl}$ & 0.013 & 58.44 & 0.747 \\
\hline $\mathrm{CrO}_{4}^{-2}$ & 0.011 & $\mathrm{Na}_{2} \mathrm{CrO}_{4} 4 \mathrm{H}_{2} \mathrm{O}$ & 0.011 & 161.97 & 1.833 \\
\hline
\end{tabular}


SRNL-STI-2010-00509

\begin{tabular}{|c|c|c|c|c|c|}
\hline $\mathrm{F}^{-1}$ & 0.003 & $\mathrm{NaF}$ & 0.003 & 41.99 & 0.137 \\
\hline $\mathrm{NO}_{3}{ }^{-1}$ & 4.215 & $\mathrm{NaNO}_{3}$ & 4.215 & 84.99 & 358.255 \\
\hline $\mathrm{NO}_{2}{ }^{-1}$ & 0.112 & $\mathrm{NaNO}_{2}$ & 0.112 & 69.00 & 7.722 \\
\hline $\mathrm{PO}_{4}^{-3}$ & 0.028 & $\mathrm{Na}_{3} \mathrm{PO}_{4} \times 12 \mathrm{H}_{2} \mathrm{O}$ & 0.028 & 380.10 & 10.519 \\
\hline $\begin{array}{c}\mathrm{SO}_{4}{ }^{-2} \\
\mathrm{C}\end{array}$ & 0.054 & $\mathrm{Na}_{2} \mathrm{SO}_{4}$ & 0.054 & 142.05 & 7.681 \\
\hline & 0.198 & $\mathrm{Na}_{2} \mathrm{CO}_{3}$ & 0.200 & 105.99 & 21.198 \\
\hline & & $\mathrm{NaHCO}_{3}$ & 0.190 & 84.006 & 15.96 \\
\hline
\end{tabular}

Table 2 AY102 data from 3/28/05, $\mathrm{pH}=10.24$

\begin{tabular}{|c|c|c|c|c|c|}
\hline & Molarity & Salt compound & Molarity & MW (g) & $\begin{array}{c}\text { Mass (g) for } \\
\mathbf{1 L}\end{array}$ \\
\hline $\mathrm{Na}^{+1}$ & 1.250 & & 1.250 & & \\
\hline $\mathrm{K}^{+1}$ & 0.004 & $\mathrm{KHCO}_{3}$ & 0.004 & 100.114 & 0.37 \\
\hline $\mathrm{Al}^{+3}$ & 0.021 & $\mathrm{NaAlO}_{2}$ & 0.021 & 81.97 & 1.74 \\
\hline $\mathrm{Br}^{-1}$ & 0.015 & $\mathrm{NaBr}$ & 0.015 & 102.89 & 1.55 \\
\hline $\mathrm{Cl}^{-1}$ & 0.001 & $\mathrm{NaCl}$ & 0.001 & 58.44 & 0.08 \\
\hline $\mathrm{CrO}_{4}{ }^{-2}$ & 0.000 & $\mathrm{Na}_{2} \mathrm{CrO}_{4} 4 \mathrm{H}_{2} \mathrm{O}$ & 0.000 & 161.97 & 0.01 \\
\hline $\mathrm{F}^{-1}$ & 0.001 & $\mathrm{NaF}$ & 0.001 & 41.99 & 0.05 \\
\hline $\mathrm{NO}_{3}^{-1}$ & 0.004 & $\mathrm{NaNO}_{3}$ & 0.004 & 84.99 & 0.34 \\
\hline $\mathrm{NO}_{2}{ }^{-1}$ & 0.296 & $\mathrm{NaNO}_{2}$ & 0.296 & 69.00 & 20.40 \\
\hline $\mathrm{PO}_{4}^{-3}$ & 0.011 & $\mathrm{Na}_{3} \mathrm{PO}_{4} \times 1_{2} \mathrm{H}_{2} \mathrm{O}$ & 0.011 & 380.10 & 4.27 \\
\hline $\mathrm{SO}_{4}^{-2}$ & 0.008 & $\mathrm{Na}_{2} \mathrm{SO}_{4}$ & 0.008 & 142.05 & 1.07 \\
\hline $\begin{array}{c}\text { Inorganic } \\
\mathrm{C}\end{array}$ & 0.405 & $\mathrm{Na}_{2} \mathrm{CO}_{3}$ & 0.370 & 105.99 & 39.22 \\
\hline & & $\mathrm{NaHCO}_{3}$ & 0.130 & 84.006 & 10.92 \\
\hline
\end{tabular}

Table 3 241-AN-107 data from 2/18/2003 (latest data is $06 / 19 / 03$ no $\mathrm{OH}$ ), $\mathrm{pH}=10.40$

\begin{tabular}{|c|c|c|c|c|c|}
\hline & Molarity & Salt compound & Molarity & MW (g) & $\begin{array}{c}\text { Mass (g) for } \\
\mathbf{1 L}\end{array}$ \\
\hline $\mathrm{Na}^{+1}$ & 8.758 & & 8.758 & & \\
\hline $\mathrm{Al}^{+3}$ & 0.043 & $\mathrm{NaAlO}$ & 0.043 & 81.97 & 3.51 \\
\hline $\mathrm{K}^{+1}$ & 0.045 & $\mathrm{KOH}$ & 0.045 & 56.11 & 2.55 \\
\hline $\mathrm{Br}^{-1}$ & 0.037 & $\mathrm{NaBr}$ & 0.037 & 102.89 & 3.81 \\
\hline $\mathrm{Cl}^{-1}$ & 0.051 & $\mathrm{NaCl}$ & 0.051 & 58.44 & 3.00 \\
\hline $\mathrm{CrO}_{4}^{-2}$ & 0.003 & $\mathrm{Na}_{2} \mathrm{CrO}_{4} 4 \mathrm{H}_{2} \mathrm{O}$ & 0.003 & 161.97 & 0.55 \\
\hline $\mathrm{F}^{-1}$ & 0.016 & $\mathrm{NaF}$ & 0.016 & 41.99 & 0.68 \\
\hline $\mathrm{NO}_{3}^{-1}$ & 3.469 & $\mathrm{NaNO}_{3}$ & 3.469 & 84.99 & 294.82 \\
\hline $\mathrm{NO}_{2}^{-1}$ & 1.492 & $\mathrm{NaNO}_{2}$ & 1.492 & 69.00 & 102.93 \\
\hline $\mathrm{PO}_{4}^{-3}$ & 0.029 & $\mathrm{Na}_{3} \mathrm{PO}_{4} \times 1_{2} \mathrm{H}_{2} \mathrm{O}$ & 0.029 & 380.10 & 11.02 \\
\hline $\mathrm{SO}_{4}^{-2}$ & 0.088 & $\mathrm{Na}_{2} \mathrm{SO}_{4}$ & 0.088 & 142.05 & 12.51 \\
\hline $\begin{array}{c}\text { Inorganic } \\
\mathrm{C}\end{array}$ & 1.259 & $\mathrm{Na}_{2} \mathrm{CO}_{3}$ & 1.260 & 105.99 & 133.40 \\
\hline & & $\mathrm{NaHCO}_{3}$ & 0.540 & 84.006 & 45.36 \\
\hline
\end{tabular}


In the testing involving a pre-salt coverage prior to electrochemical testing, the samples were dipped into the electrolyte, then raised and dried to completion. Once a dried, hardened salt deposit was present on the sample, then the sample was lowered into the electrolyte and the open circuit potential determination was immediately started.

Post-electrochemical testing, samples were submersed in Clark's solution and placed in an ultrasonicator for 2 minutes to remove corrosion product to expose surface damage. After sonication, the samples were rinsed with distilled water. Optical images were captured of the sample surface. Select samples were sent to EMSL for additional characterization using the focused-ion beam and micro-XRD.

\subsection{EFFORT 2: SIMULATED RADIATION ENVIRONMENT VESSEL DESIGN}

It is known that nitric acid forms as a result of the irradiation of moist air. The formation of a nitric acid vapor, followed by deposition onto the tank wall will accelerate corrosion in the vapor space region.

The objective of this effort is to design and test a vessel to provide a simulated radiation environment resulting in the formation of a nitric acid condensate depositing onto metallic coupons representing the tank wall. This work will develop the experimental apparatus to be utilized in interval coupon testing for investigations into solution and salt interaction in a radiological environment and the resulting corrosion that forms. Additionally, the effects of carbon dioxide and ammonia gas in the vapor space will be evaluated.

\subsection{RESULTS}

\subsection{ELECTROCHEMCAL TESTING}

\subsubsection{Pre-electrochemcal testing}

The X-ray diffraction results of the mill-scale and corroded surfaces of the A537 carbon steel were similar; with the exception that wustite $(\mathrm{FeO})$ was detected on the corroded surface. Both surfaces contained hematite $\left(\mathrm{Fe}_{2} \mathrm{O}_{3}\right)$, iron $(\mathrm{Fe})$, and magnetite $\left(\mathrm{Fe}_{3} \mathrm{O}_{4}\right)$, see Figures 1 and 2). Table 4 lists the highest intensity peaks for each compound identified. 


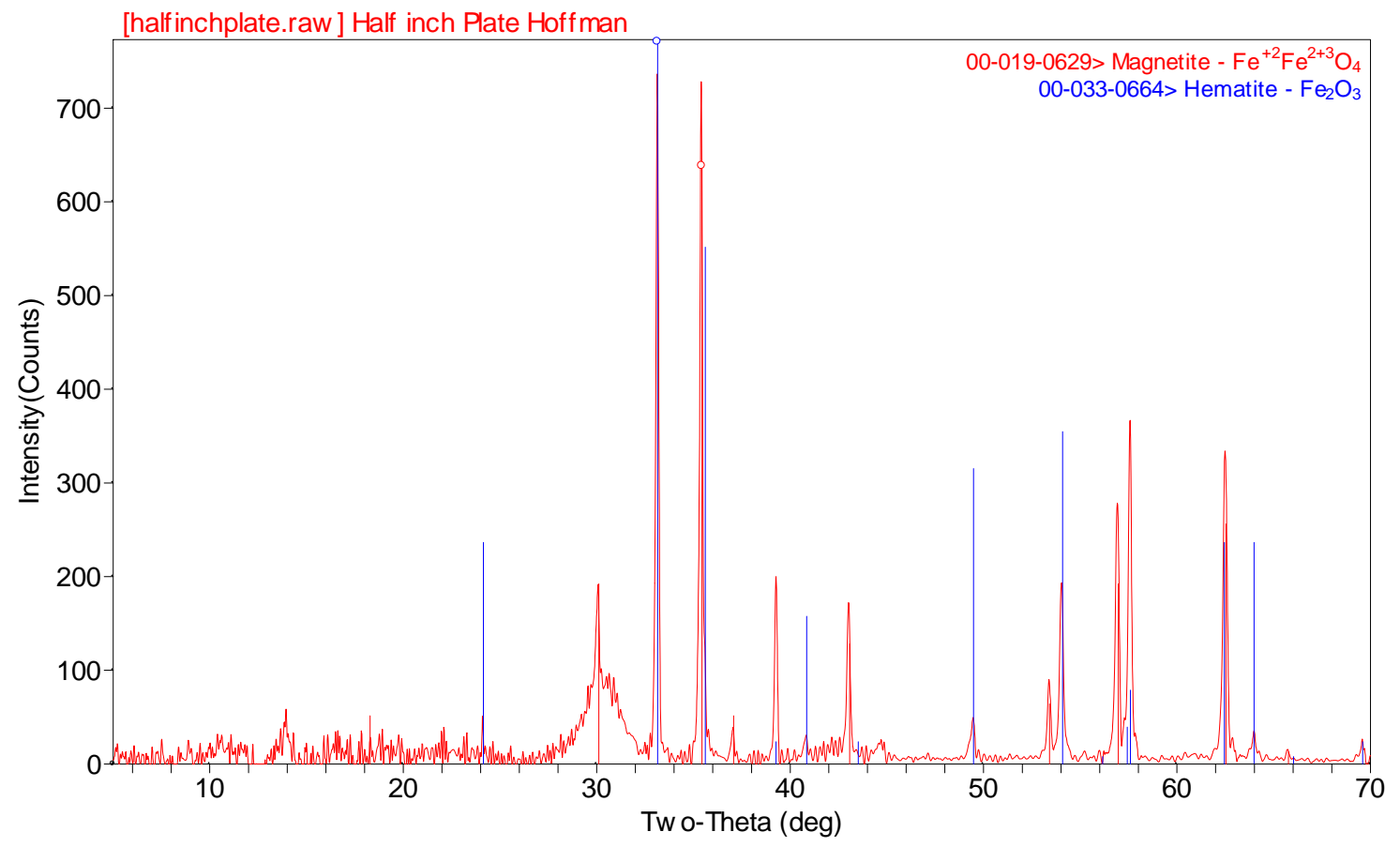

Figure 1: X-ray diffraction of mill-scale surface of A537 carbon steel.

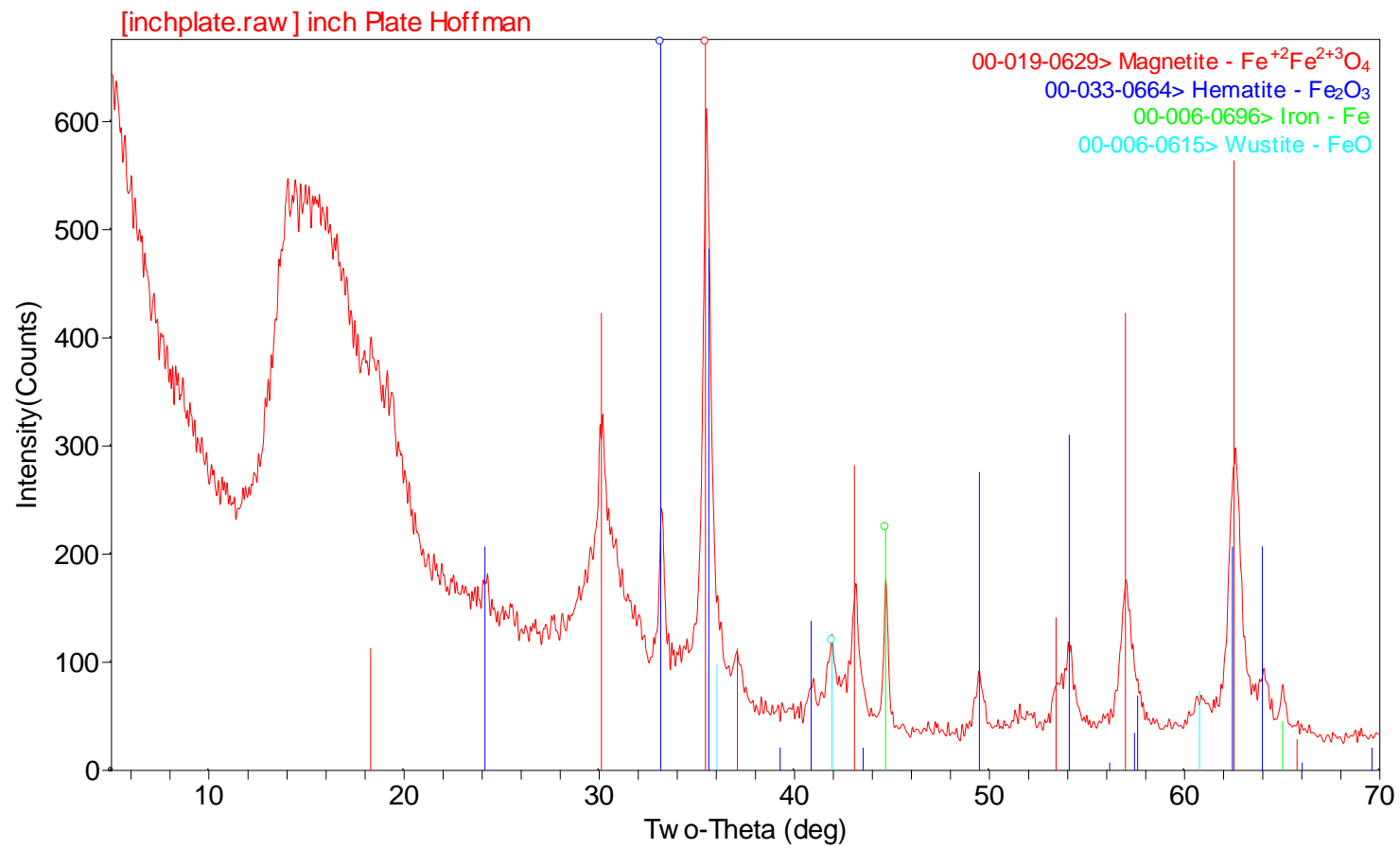

Figure 2: X-ray diffraction of corroded surface of A537 carbon steel. 
Table 4 Listing of four highest intensity $X$-ray diffraction peaks for identified compounds. Values are listed in $2 \theta$ in order of decreasing intensity.

\begin{tabular}{|c|c|c|c|}
\hline $\begin{array}{c}\text { Magnetite } \\
\left(\mathbf{F e}_{\mathbf{2}} \mathbf{O}_{\mathbf{4}}\right)\end{array}$ & $\begin{array}{c}\text { Hematite } \\
\left(\mathbf{F e}_{\mathbf{2}} \mathbf{O}_{\mathbf{3}}\right)\end{array}$ & $\begin{array}{c}\text { Iron } \\
(\mathbf{F e})\end{array}$ & $\begin{array}{c}\text { Wustite } \\
(\mathbf{F e O})\end{array}$ \\
\hline 35.423 & 33.153 & 44.674 & 41.928 \\
\hline 62.516 & 35.612 & 82.334 & 36.041 \\
\hline 56.944 & 54.090 & 65.022 & 60.766 \\
\hline 30.095 & 49.480 & 116.389 & 72.739 \\
\hline
\end{tabular}

Scanning electron micrographs show a more distinctive difference between the mill-scale and corroded surfaces. The mill-scale surface, shown in Figure 3, contains a more homogeneous oxide compared to the corroded surface, shown in Figure 4. Additionally, the micrograph shows that for the mill-scale surface, the actual mill-scale flaked off at the edges upon electro-discharge machining (EDM). This result indicates that the mill-scale, particularly at edges, is fragile, and can be damaged through machining.

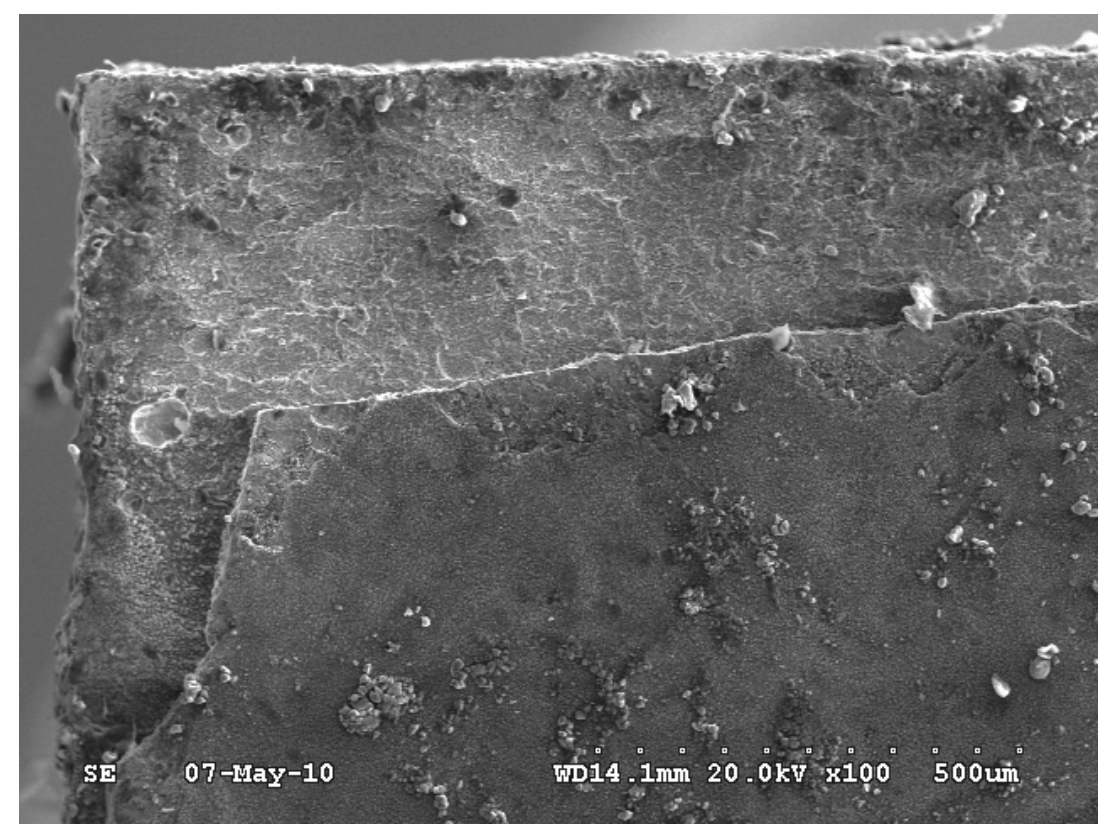

Figure 3 Mill-scale surface prior to electrochemical testing. Note, mill-scale was damaged during machining. No scale is present at the upper portion of the image. 


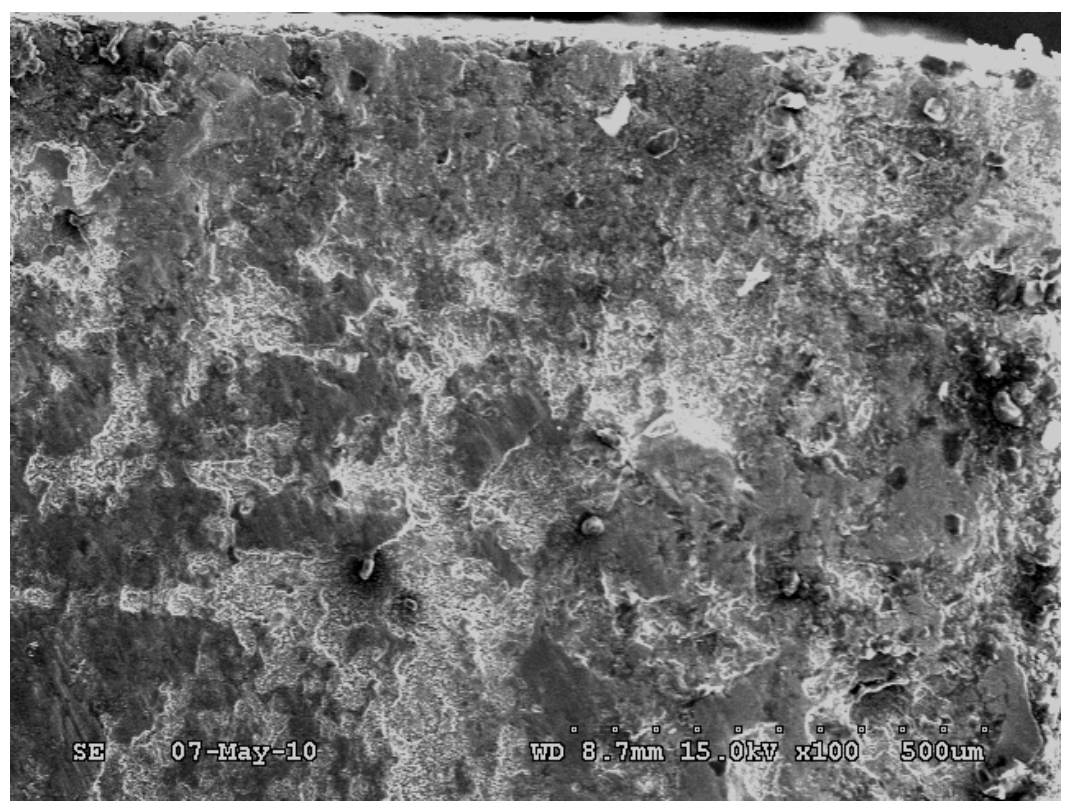

Figure 4 Corroded surface of A537 carbon steel prior to testing.

\subsubsection{CPP Curves and Corresponding Optical Images}

Cyclic potentiodynamic polarization results and corresponding optical images of the polished surfaces using SY-102 (high nitrate), AN-107, and AY-102 as electrolytes are shown in Figures 5, 6, and 7. The SY-102 (high nitrate) solution resulted in significant corrosion of the sample as shown by the optical images. The CPP curve supports this result with a positive hysteresis. The other two solutions, AN-107 and AY-102, did not result in a corrosive response and the CPP curve supports this result with a negative hysteresis.
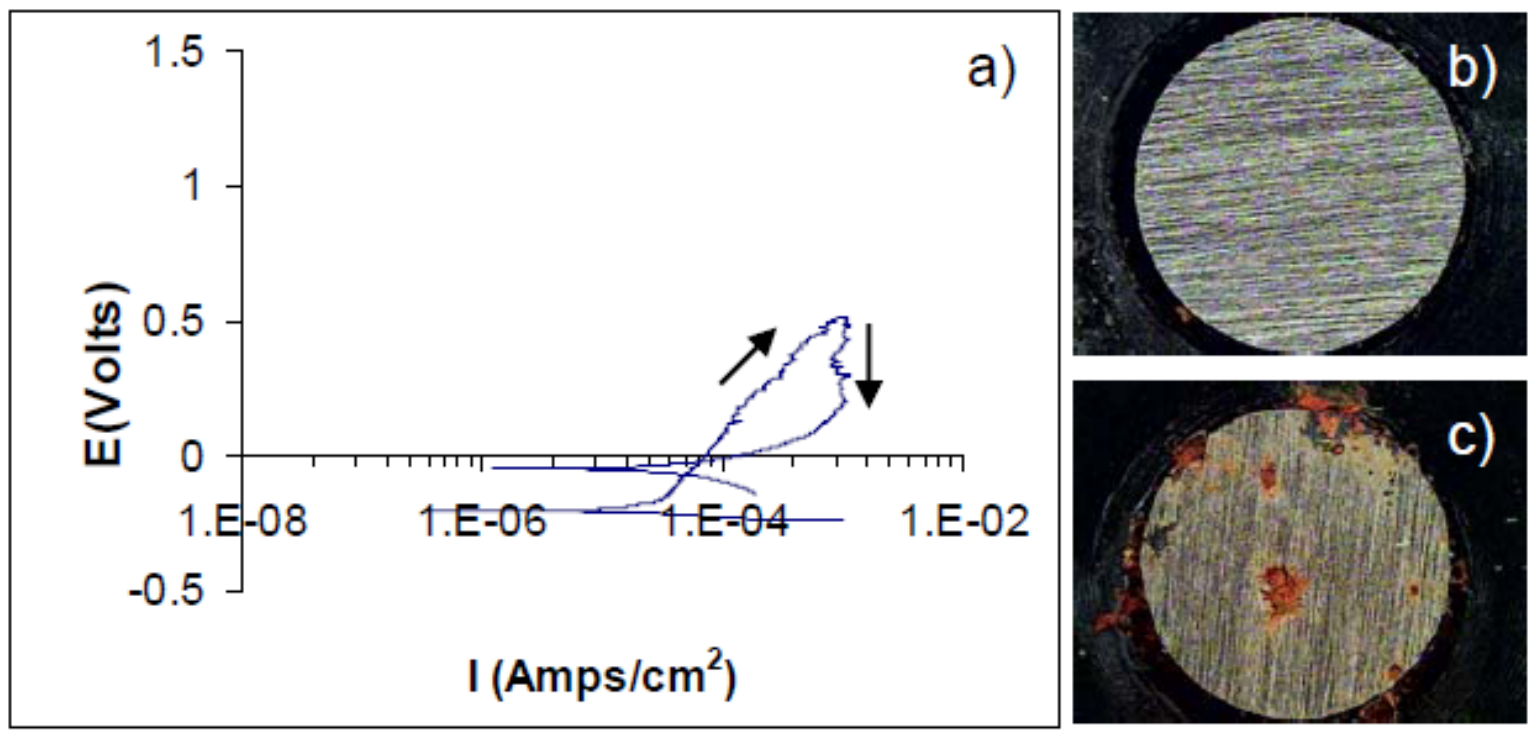

Figure 5: Polished sample tested in SY-102 (high nitrate) electrolyte: a) CPP curve, b) before electrochemical testing, c) after electrochemical testing 

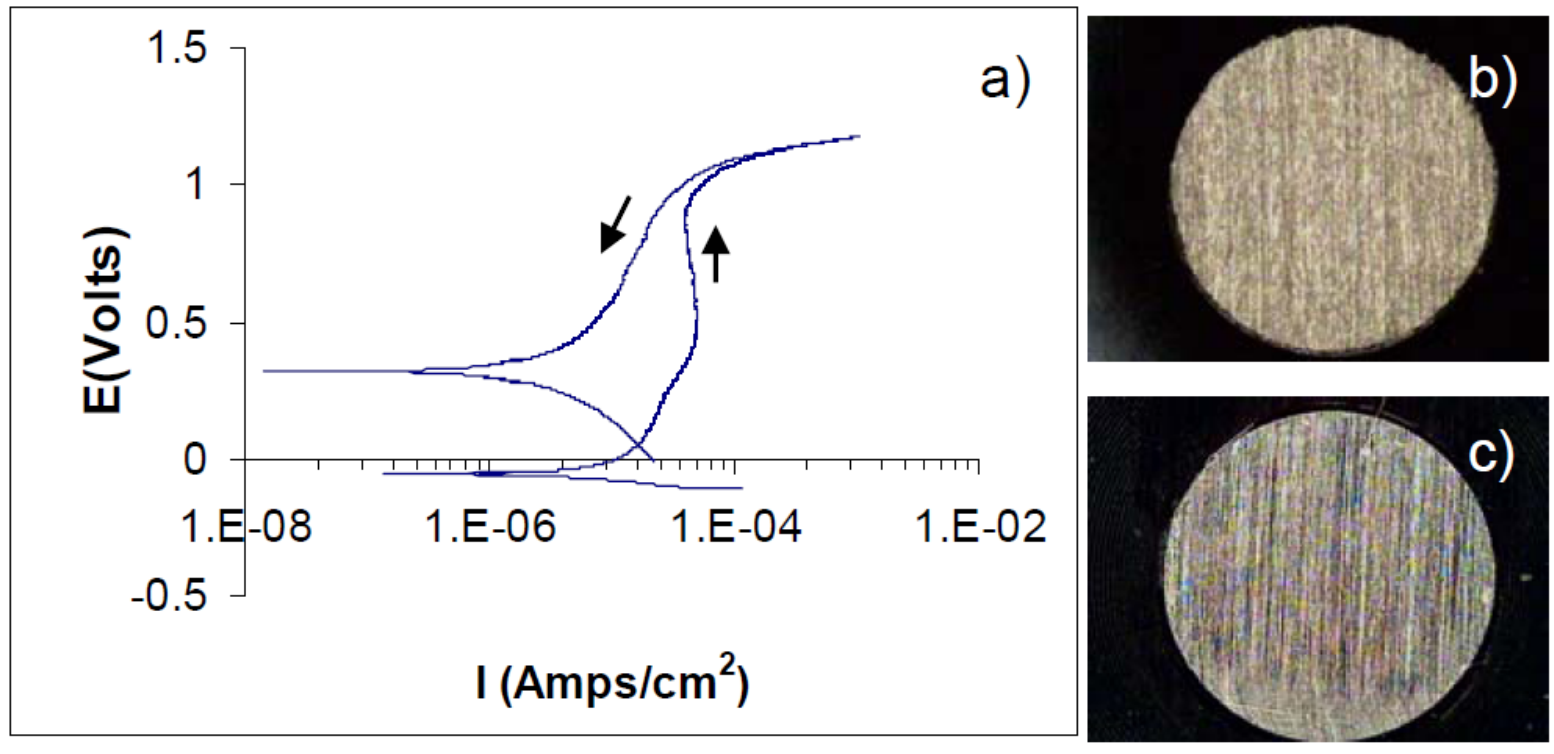

Figure 6: Polished sample tested in AN-107 electrolyte: a) CPP curve, b) before electrochemical testing, c) after electrochemical testing
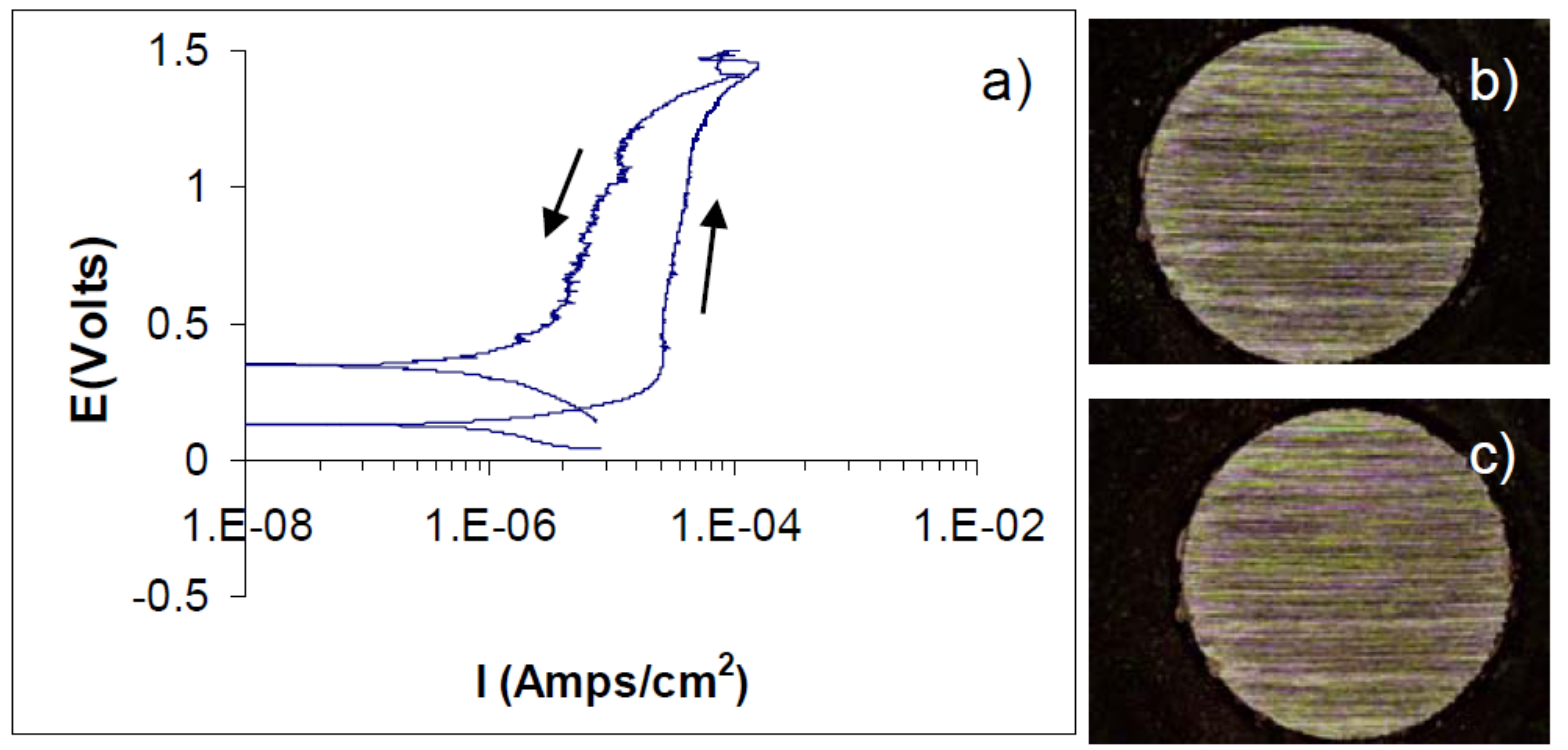

Figure 7: Polished sample tested in AY-102 electrolyte: a) CPP curve, b) before electrochemical testing, c) after electrochemical testing

A clearer breakdown potential was measured in the CPP curve and less obvious crevice attack was observed on the coupon for the pre-salt SY-102 (high nitrate) compared to the polished surface alone, see Figure 8. In solutions AN-107 and AY-102, the addition of a pre- 
salt on the polished surface did not result in a large difference in CPP and optical images, see Figures 9 and 10.
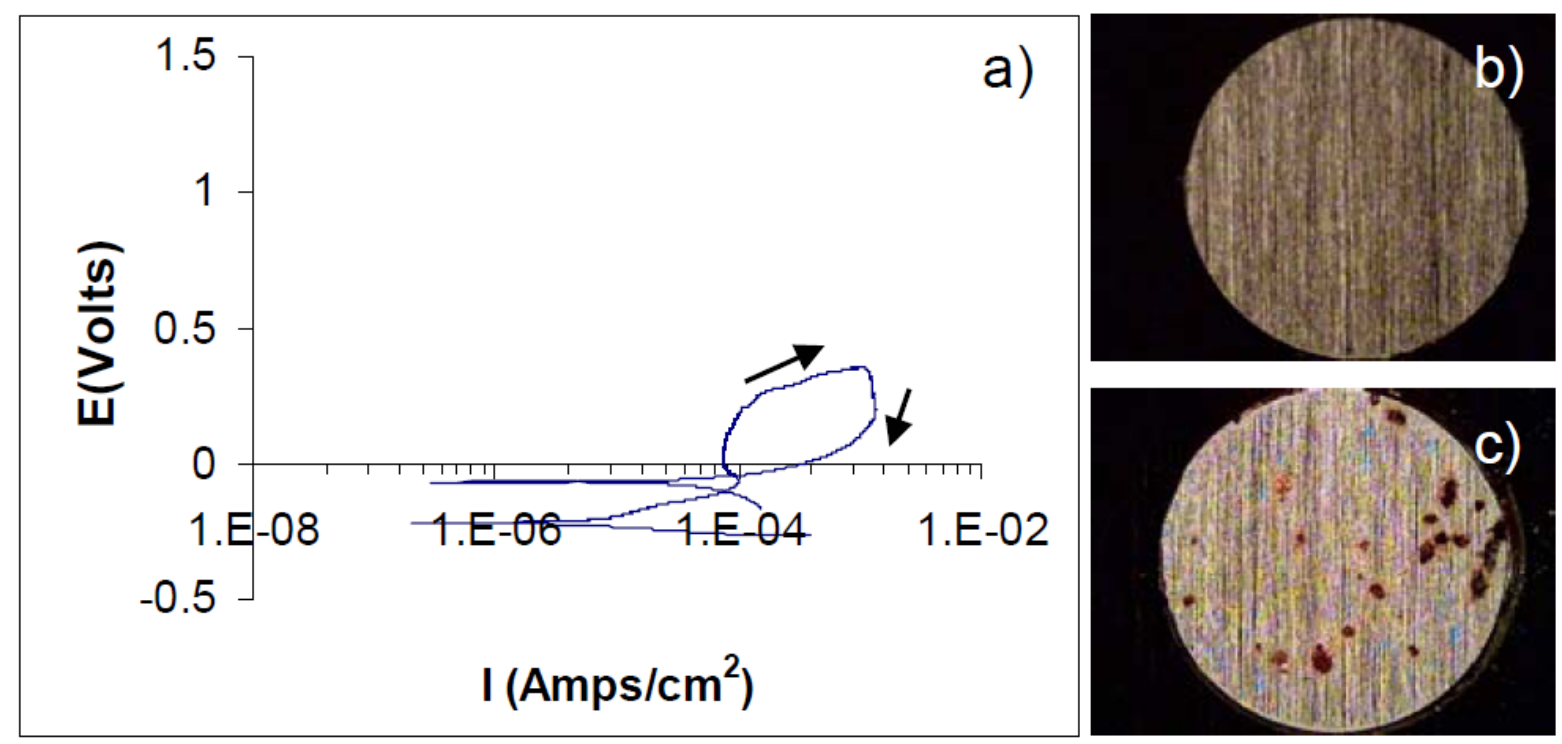

Figure 8: Polished with pre-salt sample tested in SY-102 (high nitrate) electrolyte: a) CPP curve, b) before electrochemical testing, c) after electrochemical testing
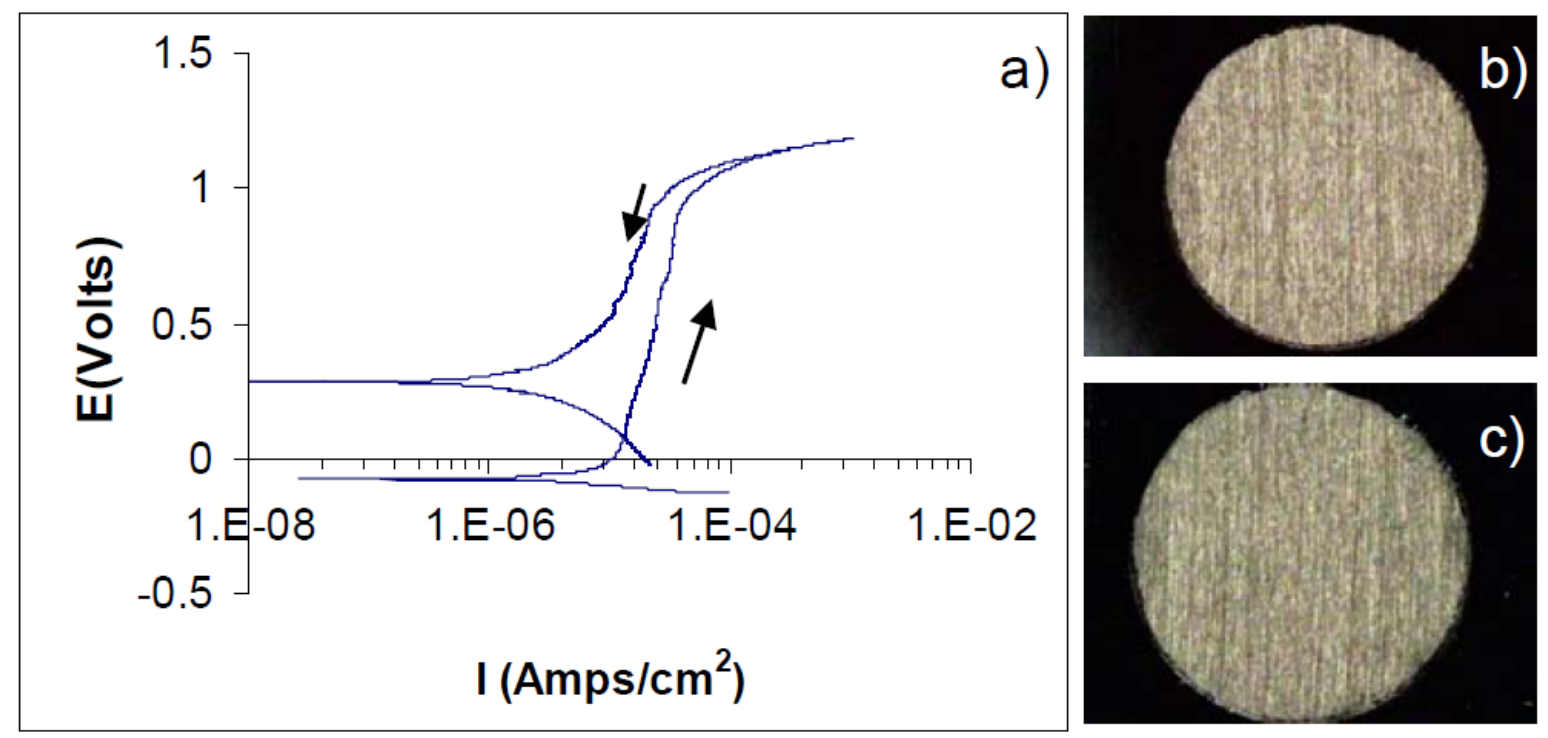

Figure 9: Polished with pre-salt sample tested in AN-107 electrolyte: a) CPP curve, b) before electrochemical testing, $c$ ) after electrochemical testing 

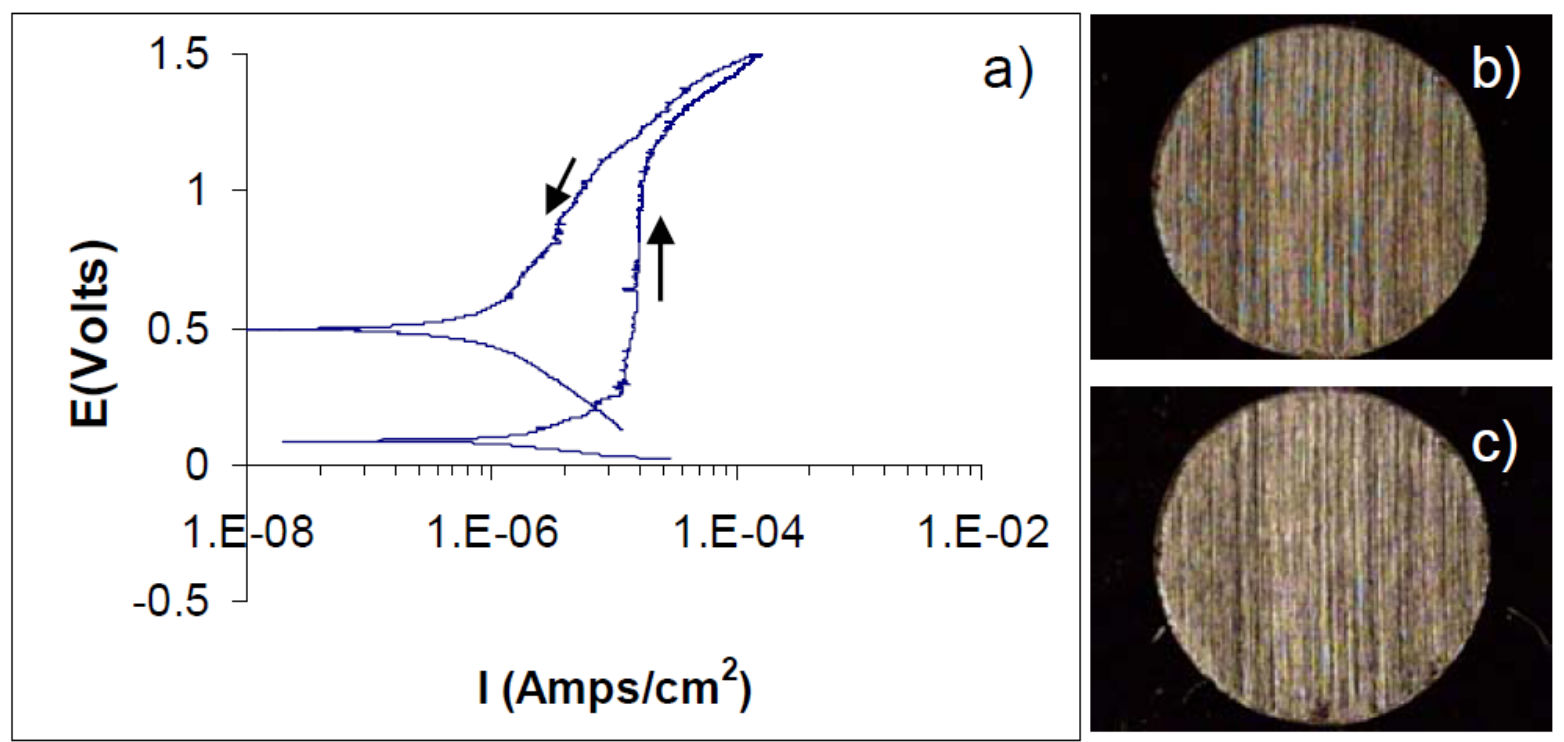

Figure 10: Polished with pre-salt sample tested in AY-102 electrolyte: a) CPP curve, b) before electrochemical testing, c) after electrochemical testing

When testing with a corroded surface, again, the SY-102 solution is the only solution that results in considerable corrosion, see Figures 11, 12, and 13. A significant portion of corrosion occurred in the form of edge attack, Figure 11. A537 samples were tapped into polymeric mounts with a pre-existing hole. Care was taken to level the surface of the blank with the surface of the metal sample; however, it was not possible to completely eliminate the height difference between the surfaces without disturbing the surface condition. In the case of SY-102 (high nitrate), the difference between the blank surface and the plastic surface was 0.0055 ”. Caution should be used when taking the edge corrosion into account as it most likely was initiated at the machined surface.
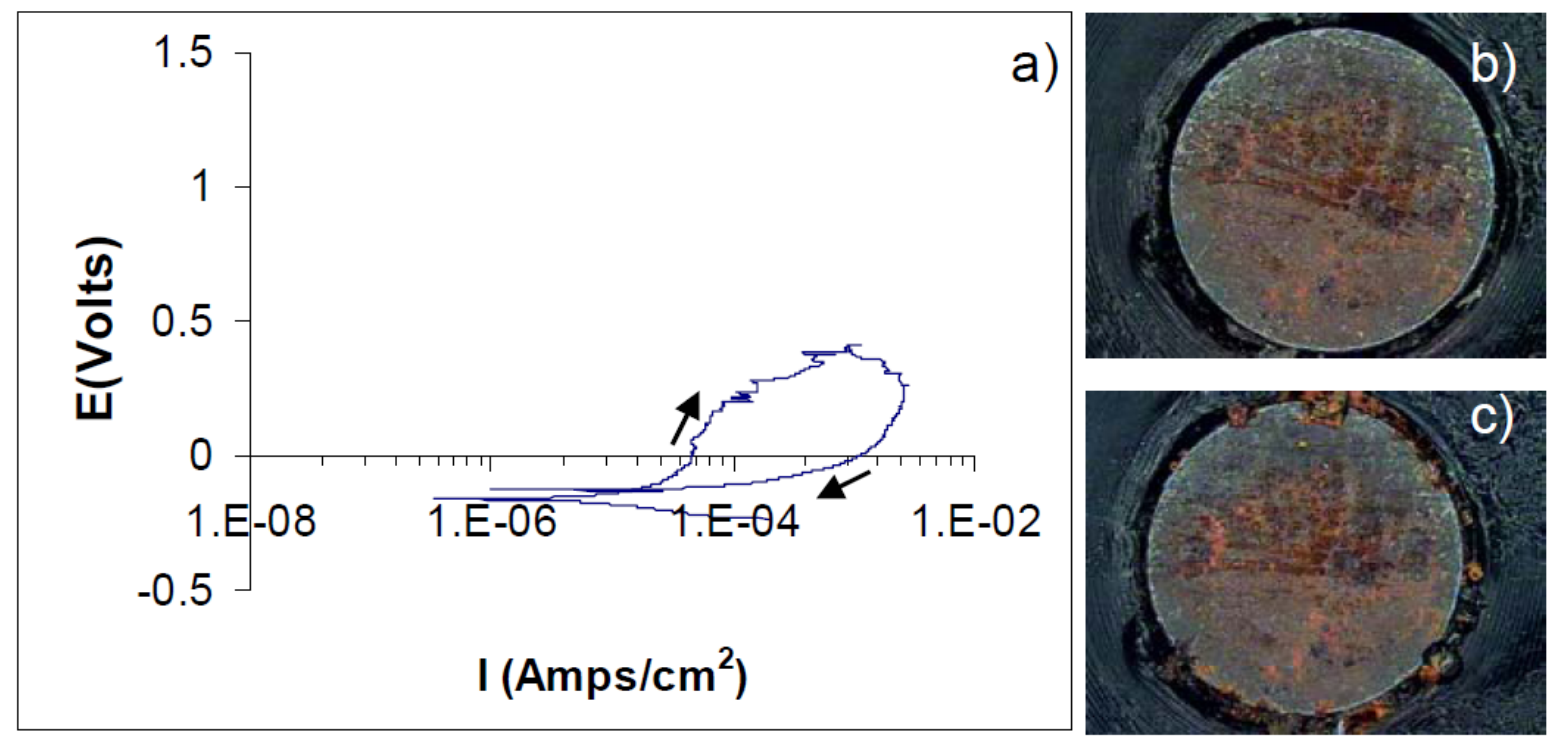

Figure 11: Corroded sample tested in SY-102 (high nitrate) electrolyte: a) CPP curve, b) before electrochemical testing, c) after electrochemical testing 

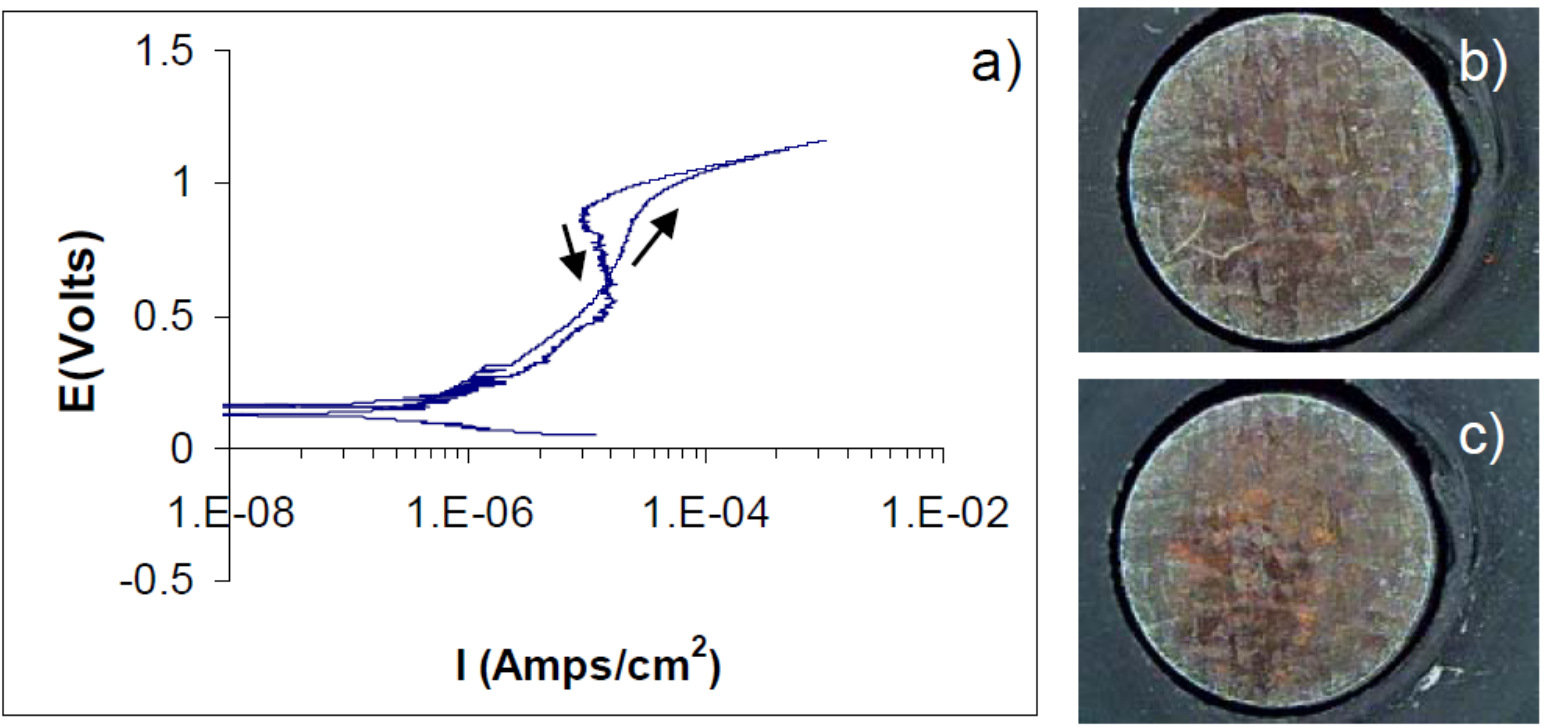

Figure 12: Corroded sample tested in AN-107 electrolyte: a) CPP curve, b) before electrochemical testing, c) after electrochemical testing
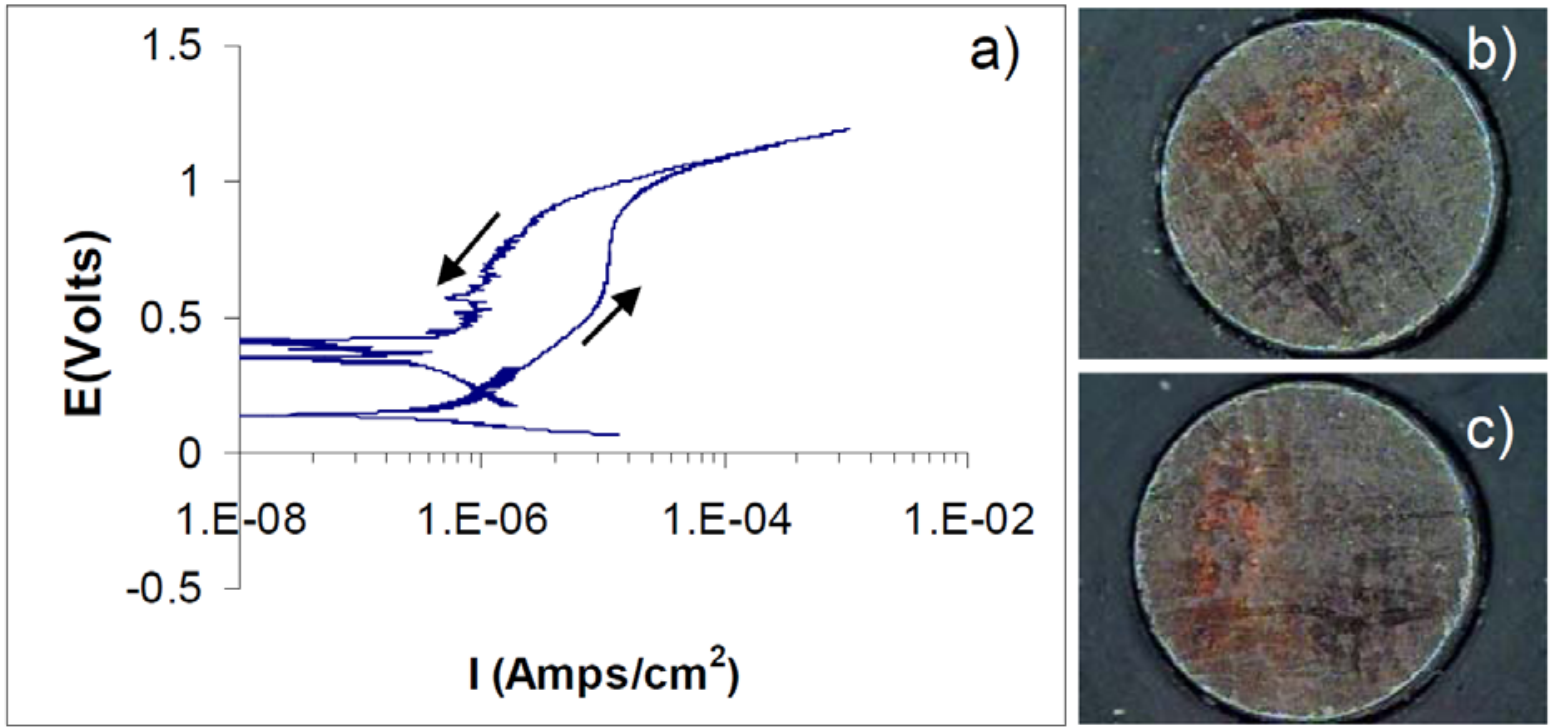

Figure 13: Corroded sample tested in AY-102 electrolyte: a) CPP curve, b) before electrochemical testing, c) after electrochemical testing

In the case of the mill-scale surface, samples exposed to SY-102 (high nitrate) corroded only in areas that were not covered by mill-scale: at the mill-scale edge and exposed machined surface due to the height difference between the sample and the plastic blank. In the case of SY-102 (high nitrate), the difference was 0.014”. The sample exposed to solution AN-107 resulted in a positive hysteresis, however, no evidence of corrosion was found on the optical image after testing. See Figures 14, 15, and 16 for results. 


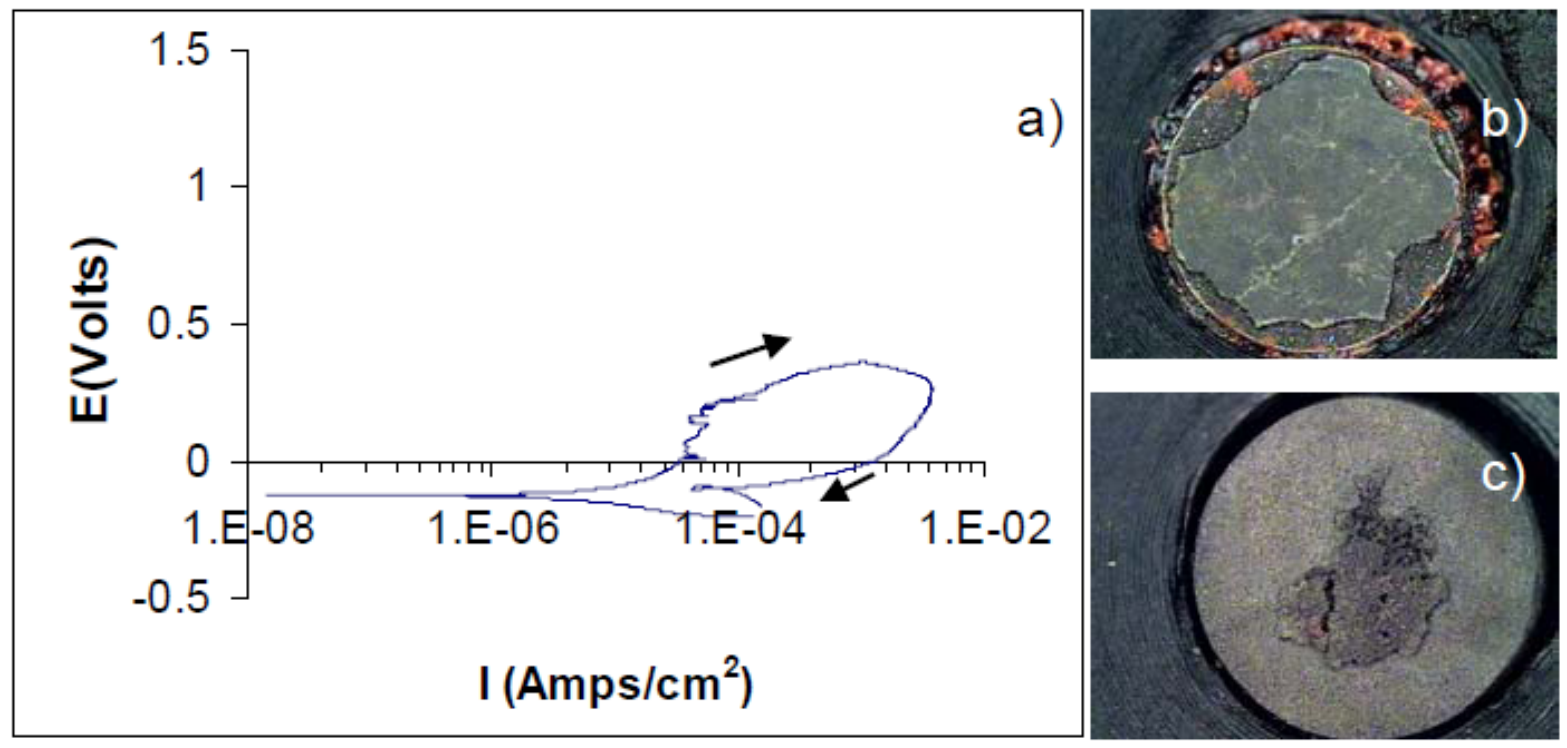

Figure 14: Mill-scale surface sample tested in SY-102 (high nitrate) electrolyte: a) CPP curve, b) after electrochemical testing, c) after cleaning.
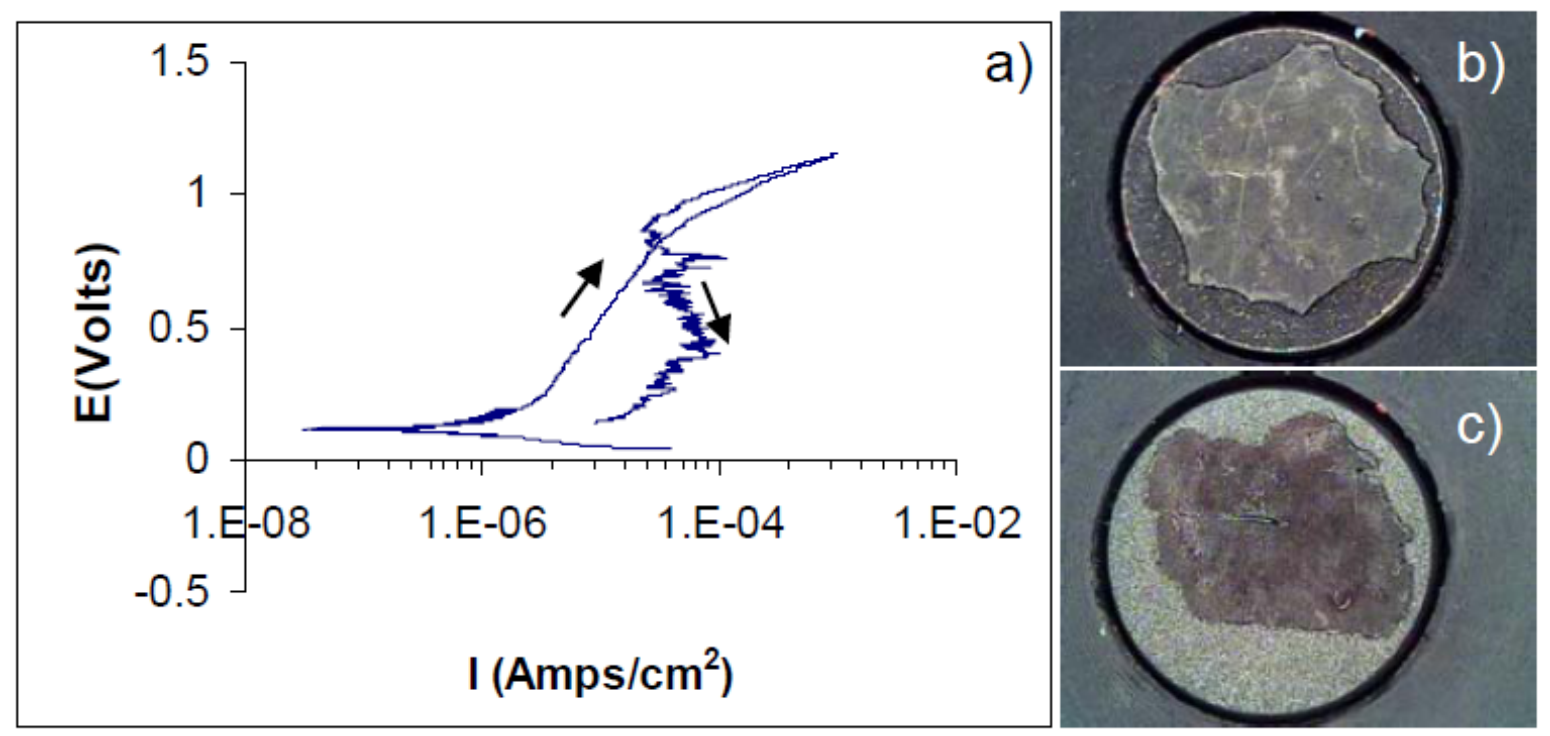

Figure 15: Mill-scale surface sample tested in AN-107 electrolyte: a) CPP curve, b) after electrochemical testing, c) after electrochemical cleaning. 

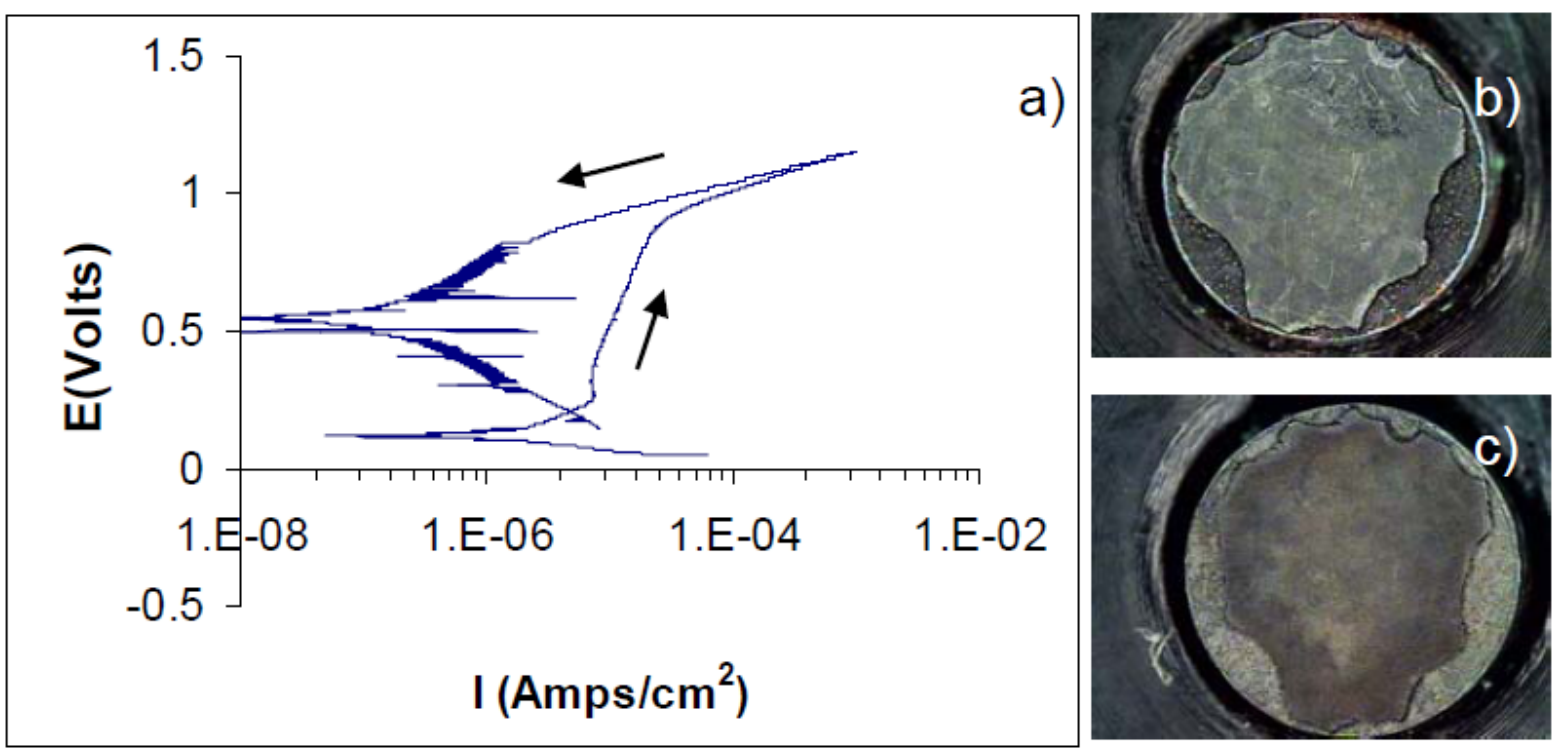

Figure 16: Mill-scale surface sample tested in AY-102 electrolyte: a) CPP curve, b) before electrochemical testing, c) after electrochemical testing

Solution SY-102 (high nitrate) was the only solution that resulted in repassivation during the reverse scan, see Table 5. Of the SY-102 (high nitrate) solutions, only the mill-scale condition did not result in a repassivation potential, $\mathrm{E}_{\mathrm{rp}}$. Values for $\mathrm{E}_{\mathrm{rp}}$ ranged from -0.028 to $-0.129 \mathrm{~V}$ for the polished and corroded surfaces, respectively. The transpassive potential,

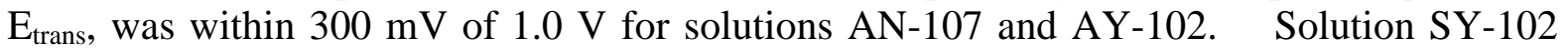
(high nitrate) measured lower pitting potentials, $\mathrm{E}_{\text {pit, }}$, ranging from $0.280 \mathrm{~V}$ for the corroded surface to $0.449 \mathrm{~V}$ for the polished surface.

Table 5 Electrochemical parameters, $\mathbf{E}_{\text {cor }}, \mathbf{E}_{\text {pit }}, \mathbf{E}_{\text {trans }}$ and $\mathbf{E}_{\mathrm{rp}}$, based on electrochemical scans. Note, $\mathbf{E}_{\text {pit }}$ pertains to $\mathrm{SY}-102$ (high nitrate solutions), $\mathbf{E}_{\text {trans }}$ pertains to $\mathrm{AN}-107$ and AY-102 solutions.

\begin{tabular}{|c|c|c|c|c|}
\hline Solution & Sample Surface & $\mathbf{E}_{\text {cor }}(\mathbf{V})$ & $\mathbf{E}_{\text {pit }}$ or $\mathbf{E}_{\text {trans }}(\mathbf{V})$ & $\mathbf{E}_{\mathbf{r p}}(\mathbf{V})$ \\
\hline AN-107 & Corroded & 0.126 & 0.961 & -- \\
\hline AN-107 & Polished & -0.053 & 0.990 & -- \\
\hline AN-107 & Polished with Pre-salt & -0.074 & 1.005 & -- \\
\hline AN-107 & Mill-scale & 0.125 & 0.920 & -- \\
\hline AY-102 & Corroded & 0.152 & 0.935 & -- \\
\hline AY-102 & Polished & 0.127 & 1.287 & -- \\
\hline AY-102 & Polished with Pre-salt & 0.089 & 1.169 & -- \\
\hline AY-102 & Mill-scale & 0.119 & 0.925 & -- \\
\hline SY-102 (high nitrate) & Corroded & -0.161 & 0.280 & -0.129 \\
\hline SY-102 (high nitrate) & Polished & -0.205 & 0.449 & -0.028 \\
\hline SY-102 (high nitrate) & Polished with Pre-salt & -0.222 & 0.272 & -0.047 \\
\hline SY-102 (high nitrate) & Mill-scale & -0.123 & 0.304 & -- \\
\hline
\end{tabular}


Due to the break-off of mill-scale from the machining process, the reproducibility of the millscale CPP curves was evaluated by running multiple mill-scale surface samples. It was found that the reproducibility of the CPP curves was on the order of $+/-150 \mathrm{mV}$. This result is consistent with runs using polished surface samples.

\subsection{SIMULATED RADIATION VESSEL}

A glass vessel capable of holding 3 liters of solution has been designed and fabricated, see Figure 17. The vessel creates a simulated radiation environment by providing a nitric acid vapor environment. Additionally, the vessel has the flexibility to also provide a nitric acid and ammonia vapor environment via a connection to a gas mixture of $20 \mathrm{ppm} \mathrm{NO}_{2}$ and 50 ppm $\mathrm{NH}_{3}$. A salt solution will be added to the vessel to control the relative humidity based on ASTM E104-02. Corrosion samples can be suspended from two different rods at two different levels within the vapor space. The rods and sample spacers are made from Teflon to prevent galvanic corrosion.

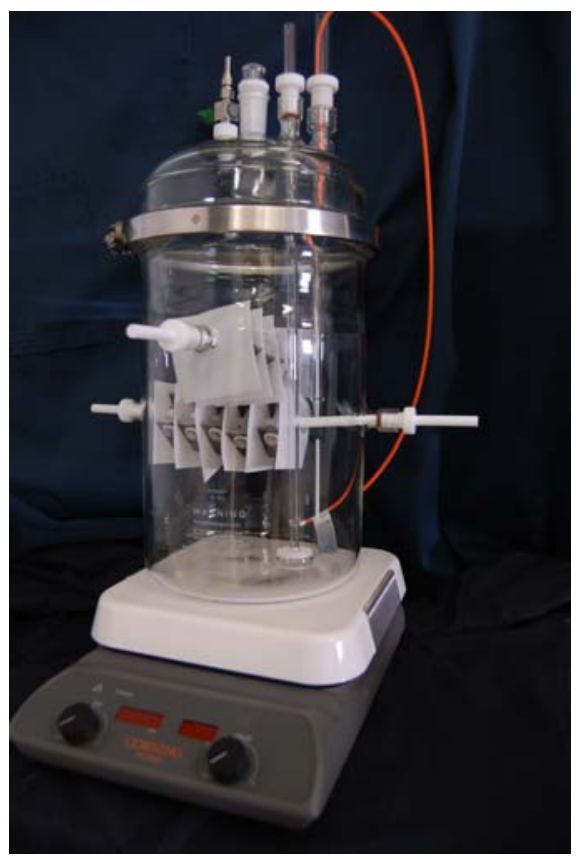

Figure 17: The simulated radiation environment vessel equipped with two Teflon hanging rods, ports for gas inlet and outlet, a safety pressure relief plug, and optional solution bubbler.

\subsection{DISCUSSION}

Based on both cyclic potentiodynamic polarization curves and corresponding optical image results, the solution SY-102 is considerably more corrosive than the AY-102 and AN-107 solutions. The major difference in the solutions is that the SY-102 (high nitrate) solution has more nitrate, $4.215 \mathrm{M}$ molarity, compared to the other two solutions, $0.004 \mathrm{M}$ and $3.469 \mathrm{M}$, respectively, see Tables 1-3. When the ratio of nitrate to nitrite (aggressor to inhibitor species) per solution is calculated, the difference between the SY-102 (high nitrate) solution 
and the other two solutions is further magnified. The ratio of $\mathrm{NO}_{2} / \mathrm{NO}_{3}$ for the SY-102 (high nitrate) solution is 0.026 versus 100 and 0.431 for the AY-102 and AN-107, respectively. AY-102 is not a nitrate-ion waste, but a carbonate-ion waste, which yields a significantly higher $\mathrm{NO}_{2} / \mathrm{NO}_{3}$ ratio compared to $\mathrm{AN}-107$ and SY-102 (high nitrate).

The effect of the surface condition prior to testing did not play as large of a role compared to the solution chemistry of the electrolyte used. The pre-salt formed directly from the testing solution did not result in a significant change in the electrochemical response. The corroded surface also did not play a significant role in affecting the corrosion response. While the mill-scale surface, did not result in a significant change in the corrosion response compared to the polished surface, it did yield results of interest when comparing the optical images before and after cleaning with Clark's solution. Corrosion at the edge of the mill-scale appeared to occur in the SY-102 (high nitrate) solution, see Figure 14b. After cleaning all three mill-scale samples with Clark's solution, a higher percentage of mill-scale on the SY102 (high nitrate) sample was removed due to the cleaning process, see Figure 14c. The sample with the least mill-scale loss was AY-102, which also had the lowest ratio of $\mathrm{NO}_{3} / \mathrm{NO}_{2}$. The loss of mill-scale on the samples is most likely due to a corrosive attack occurring at the edge of the mill-scale, then spreading to under the mill-scale. This reaction could have resulted in the breakdown of the mill-scale adhesion to the sample surface. Therefore, while mill-scale itself is protective against corrosion, when exposed to a corrosive solution, the scale can be compromised through crevice attack.

\subsection{CONCLUSIONS}

Out of three solutions tested, both optical and electrochemical results show that carbon steel corroded much faster in SY-102 (high nitrate) compared to the other two solutions, AN-107 and AY-102, with lower ratios of nitrate to nitrite. The effect of the surface preparation was not as strong as the effect of solution chemistry. In areas with pristine mill-scale surface, no corrosion occurred even in the SY-102 (high nitrate) solution, however, corrosion occurred in the areas where the mill-scale was damaged or flaked off due to machining.

\subsection{REFERENCES}

[1] Electrochemical Techniques in Corrosion Science and Engineering, R.G. Kelly, J.R. Scully, D.W. Shoesmith, R.G. Buchheit (2003) Taylor \& Francis Group: Boca Raton

[2] Y. Kanda, T. Miura, H. Nakajima, Radiation Physics and Chemistry 77 [7] (2008) 884888

[3] M. Terry, J. Beavers, G. Frankel, J. Huckaby, L. Stock, K. Subramanian, B. Wiersma, "Expert Panel Workshop on Double-Shell Tank Vapor Space Corrosion Testing”, RPP-RPT31129, (2006) 